\title{
Agromyces subbeticus sp. nov., isolated from a cave in southern Spain
}

\author{
Valme Jurado, ${ }^{1}$ Ingrid Groth, ${ }^{2}$ Juan M. Gonzalez, ${ }^{1}$ Leonila Laiz ${ }^{1}$ \\ and Cesareo Saiz-Jimenez ${ }^{1}$ \\ ${ }^{1}$ Instituto de Recursos Naturales y Agrobiología, CSIC, Apartado 1052, 41080 Sevilla, Spain \\ ${ }^{2}$ Hans-Knöll-Institut für Naturstoff-Forschung e.V., D-07745 Jena, Germany
}

Correspondence
Cesareo Saiz-Jimenez

saiz@irnase.csic.es

\begin{abstract}
An actinomycete, strain $Z 33^{\top}$, was isolated from a cyanobacterial biofilm in the Cave of Bats, near Zuheros (Cordoba, southern Spain). 16S rRNA gene sequence analysis showed that strain $\mathrm{Z}_{3}{ }^{\top}$ formed a distinct phyletic line within the genus Agromyces. This isolate could be readily distinguished from representatives of all recognized Agromyces species on the basis of a broad range of phenotypic characteristics and DNA-DNA relatedness data. Genotypic and phenotypic properties indicate that strain $Z 33^{\top}$ represents a novel species, for which the name Agromyces subbeticus sp. nov. is proposed. The type strain is $Z 33^{\top}\left(=\mathrm{HKI} 0340^{\top}=\mathrm{DSM}\right.$ $16689^{\top}=\mathrm{NCIMB} 14025^{\top}$ ).
\end{abstract}

Since the description of the genus Agromyces by Gledhill \& Casida (1969) with the type species Agromyces ramosus, the number of recognized species in the genus has increased to 16 , and studies have indicated that these are widely distributed in nature and might play a significant role in a variety of ecosystems. Agromyces cerinus subsp. cerinus and Agromyces cerinus subsp. nitratus were described by Zgurskaya et al. (1992), Agromyces mediolanus by Suzuki et al. (1996), Agromyces luteolus, Agromyces rhizospherae and Agromyces bracchium by Takeuchi \& Hatano (2001), Agromyces aurantiacus by Li et al. (2003), Agromyces albus by Dorofeeva et al. (2003) and Agromyces ulmi by Rivas et al. (2004). A reclassification of Agromyces fucosus subsp. fucosus and Agromyces fucosus subsp. hippuratus as Agromyces fucosus and Agromyces hippuratus, respectively, was proposed by Ortiz-Martinez et al. (2004). Studies on the diversity and role of Agromyces species in hypogean environments resulted in the description of two novel species, Agromyces salentinus and Agromyces neolithicus, which were isolated from an Italian cave (Jurado et al., 2005a), and three novel species, Agromyces italicus, Agromyces humatus and Agromyces lapidis (Jurado et al., 2005b), originating from Roman catacombs.

The aim of the present study was to determine the taxonomic position of a further cave isolate, strain $\mathrm{Z}_{3} 3^{\mathrm{T}}$. On the basis of the results presented below, strain $\mathrm{Z}_{3} 3^{\mathrm{T}}$ is considered to represent a novel species of the genus Agromyces.

Published online ahead of print on 29 April 2005 as DOI 10.1099/ ijs.0.63637-0.

The GenBank/EMBL/DDBJ accession number for the 16S rRNA gene sequence of strain $Z_{3} 3^{\top}$ is $A Y 737778$.
Strain $\mathrm{Z}_{3} 3^{\mathrm{T}}$ was isolated from a blue-grey cyanobacterial biofilm covering the walls of the Cave of Bats (Zuheros, Cordoba, southern Spain) on PY-BHI medium (Yokota et al., 1993) at $28^{\circ} \mathrm{C}$. Laboratory cultivation of strain ${\mathrm{Z} 33^{\mathrm{T}}}^{\mathrm{T}}$ was performed on medium 79 (OM79) (Prauser \& Falta, 1968; Jurado et al., 2005a).

All experimental methods used in this study are as described by Jurado et al. (2005a). The range of $\mathrm{pH}$ for growth was established using liquid OM79 medium adjusted to initial $\mathrm{pH}$ values of 4-11 with either $1 \mathrm{M} \mathrm{HCl}$ or $20 \%$ (w/v) $\mathrm{Na}_{2} \mathrm{CO}_{3}$ solution and incubated at $28^{\circ} \mathrm{C}$ for up to 10 days.

The following type strains were used as references for comparative studies: A. fucosus IMET $11529^{\mathrm{T}}$, A. ramosus IMET $11027^{\mathrm{T}}$, A. albus VKM $1800^{\mathrm{T}}$, A. cerinus subsp. nitratus IMET $11532^{\mathrm{T}}$ and A. cerinus subsp. cerinus IMET $11525^{\mathrm{T}}$.

Morphological and physiological traits are summarized under the species description below and in Table 1. Chemotaxonomic characteristics are given in Table 2.

$16 \mathrm{~S}$ rRNA gene sequence analysis showed that strain $\mathrm{Z}_{3}{ }^{\mathrm{T}}$ had closest phylogenetic relationships to A. fucosus $(97 \cdot 6 \%$ sequence similarity), A. ramosus (95.3\%), A. albus (95.1\%), A. cerinus subsp. cerinus $(95 \cdot 0 \%)$ and A. cerinus subsp. nitratus $(92 \cdot 1 \%)$. Sequence alignment was performed using the software suite ARB (Ludwig et al., 2004). Alignment was manually edited considering the expected sequence secondary structure. An unrooted phylogenetic tree was constructed by the neighbour-joining method through the ARB suite. The tree topology obtained was reconstructed by quartet-puzzling using the program TREEPUZZLE (Strimmer \& von Haeseler, 1996) available within the ARB package. The quartet-puzzling tree represented a consensus tree showing 
Table 1. Characteristics that differentiate strain $Z 33^{\top}$ from its closest relatives within the genus Agromyces

Taxa: $1, \mathrm{Z}^{\mathrm{T}}{ }^{\mathrm{T}} ; 2$, A. fucosus; 3, A. ramosus; 4, A. albus; 5, A. cerinus subsp. nitratus; 6, A. cerinus subsp. cerinus. - , Negative; + , positive; $(+)$, weakly positive; $+/-$, variable; ${ }^{\star}$, delayed; ND, not determined; tr, trace. Data from this study unless indicated.

\begin{tabular}{|c|c|c|c|c|c|c|}
\hline Characteristic & 1 & 2 & $3 \dagger$ & 4 & 5 & $6 \dagger$ \\
\hline Colony colour $\ddagger$ & $\mathrm{Y}$ & $\mathrm{Y}$ & $\mathrm{W}$ & $\mathrm{W}$ & Y & Y \\
\hline DNA G $+C$ content $(\mathrm{mol} \%)$ & $71 \cdot 2$ & $70 \cdot 6$ & $68 \cdot 9$ & $69 \cdot 0$ & $70 \cdot 9$ & $70 \cdot 5$ \\
\hline Growth at $37^{\circ} \mathrm{C}$ & $\operatorname{tr}$ & + & + & + & $(+)^{*}$ & ND \\
\hline \multicolumn{7}{|c|}{ Decomposition or hydrolysis of: } \\
\hline Casein & + & + & - & + & + & - \\
\hline Gelatin & $+1-$ & + & - & + & - & - \\
\hline Hippurate & + & + & + & + & + & - \\
\hline Hypoxanthine & + & + & - & - & + & $(+)$ \\
\hline Tyrosine & + & + & - & - & + & + \\
\hline Urea & - & - & - & + & - & - \\
\hline Xanthine & + & + & - & - & - & - \\
\hline \multicolumn{7}{|l|}{ Biochemical tests } \\
\hline Nitrate reduction & - & - & $+1-$ & - & + & - \\
\hline Catalase reaction & + & + & - & + & + & + \\
\hline Oxidase test & $+1-$ & + & - & + & $+1-$ & + \\
\hline Microaerophilic growth & + & + & + & - & + & $-{ }^{a}$ \\
\hline \multicolumn{7}{|c|}{ Acid production from (API $50 \mathrm{CH} \mathrm{B/E}$ ): } \\
\hline Adonitol & - & - & $-{ }^{b}$ & + & - & $-{ }^{b}$ \\
\hline Amygdalin & + & + & $+^{b}$ & - & + & $+^{b}$ \\
\hline L-Arabinose & + & + & + & + & - & - \\
\hline Cellobiose & + & + & - & - & + & + \\
\hline D-Fucose & - & - & $-{ }^{b}$ & $(+)$ & - & $-{ }^{b}$ \\
\hline L-Fucose & + & + & $++^{b}$ & - & + & $(+)^{b}$ \\
\hline Galactose & + & + & - & $(+)$ & + & + \\
\hline D-Glucose & + & + & - & $(+)$ & + & + \\
\hline Glycerol & + & + & + & - & + & + \\
\hline Inulin & + & $(+)$ & + & - & - & - \\
\hline Lactose & $(+)$ & - & - & - & - & + \\
\hline Methyl $\alpha$-D-mannoside & + & + & $-{ }^{b}$ & - & - & $-{ }^{b}$ \\
\hline Methyl $\alpha$-D-glucoside & - & + & $-{ }^{b}$ & - & - & $-{ }^{b}$ \\
\hline Maltose & + & + & - & + & + & + \\
\hline Mannitol & + & - & $(+)$ & + & - & - \\
\hline Mannose & + & + & - & $(+)$ & + & + \\
\hline Melibiose & - & - & $-{ }^{b}$ & $(+)$ & - & $-{ }^{b}$ \\
\hline $\mathrm{N}$-Acetylglucosamine & $+1-$ & + & $+^{b}$ & - & + & $--^{b}$ \\
\hline D-Raffinose & + & + & + & $+^{*}$ & - & - \\
\hline Ribose & - & - & - & $+^{*}$ & - & - \\
\hline Salicin & + & + & - & - & + & + \\
\hline Sucrose & + & + & + & $(+)$ & - & + \\
\hline Trehalose & - & $(+)^{*}$ & - & - & - & - \\
\hline D-Xylose & + & - & - & $+^{*}$ & - & - \\
\hline \multicolumn{7}{|l|}{ Utilization of: } \\
\hline Aconitate & - & - & - & - & - & + \\
\hline Citrate & - & - & - & - & - & + \\
\hline Malate & + & - & + & + & - & + \\
\hline Succinate & + & - & + & + & - & - \\
\hline \multicolumn{7}{|l|}{ Enzyme assays (API ZYM) } \\
\hline$\alpha$-Galactosidase & - & - & $-{ }^{b}$ & - & + & $+^{b}$ \\
\hline$\beta$-Galactosidase & + & + & $-{ }^{b}$ & + & + & $+^{b}$ \\
\hline$\alpha$-Glucosidase & + & + & $-{ }^{b}$ & + & + & $++^{b}$ \\
\hline
\end{tabular}


Table 1. cont.

\begin{tabular}{|c|c|c|c|c|c|c|}
\hline Characteristic & 1 & 2 & $3 \dagger$ & 4 & 5 & $6 \dagger$ \\
\hline$N$-Acetyl- $\beta$-glucosaminidase & + & + & $-{ }^{b}$ & + & - & $-{ }^{b}$ \\
\hline$\alpha$-Fucosidase & - & - & $-{ }^{b}$ & - & + & $-{ }^{b}$ \\
\hline \multicolumn{7}{|l|}{ Antibiotic sensitivity } \\
\hline Ampicillin $(10 \mu \mathrm{g})$ & - & - & + & + & - & + \\
\hline Ciprofloxacin $(5 \mu \mathrm{g})$ & + & + & + & + & - & $+1-$ \\
\hline Kanamycin $(30 \mu \mathrm{g})$ & - & + & + & + & + & + \\
\hline Nalidixic acid $(30 \mu \mathrm{g})$ & - & - & $-{ }^{b}$ & + & - & $-{ }^{b}$ \\
\hline Novobiocin $(5 \mu \mathrm{g})$ & + & + & $-{ }^{b}$ & + & + & $+{ }^{b}$ \\
\hline Penicillin G (10 IU) & - & - & + & - & - & - \\
\hline Polymyxin B (300 IU) & - & - & + & + & + & $+1-$ \\
\hline Tetracycline $(30 \mu \mathrm{g})$ & + & + & $-{ }^{b}$ & + & + & $+^{b}$ \\
\hline
\end{tabular}

$\dagger$ Data from Groth et al. (1996) except where indicated by: $a$, data from Dorofeeva et al. (2003); $b$, data from this study.

$\ddagger$ W, White; Y, yellow.

well-supported branching, and was based on 1000 puzzling trials. The reliability value of each internal branch indicates as a percentage how often the corresponding cluster was found. Fig. 1 shows the proposed phylogenetic relationships between the members of the genus Agromyces and

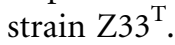

The DNA $\mathrm{G}+\mathrm{C}$ content of strain $\mathrm{Z}^{\mathrm{T}} 3^{\mathrm{T}}$ was $71 \cdot 2 \mathrm{~mol} \%$, which is in agreement with the values observed within the genus Agromyces (68.9-72.8 mol\%; Dorofeeva et al., 2003). The degree of DNA-DNA relatedness between the Agromyces type strains investigated and strain $\mathrm{Z33}^{\mathrm{T}}$ was determined by two independent methods: the DNA-DNA hybridization method described by Ziemke et al. (1998)

Table 2. Chemotaxonomic characteristics of strain $Z 33^{\top}$

Abbreviations: Gal, galactose; Glc, glucose; Man, mannose; Rha, rhamnose; DAB, diaminobutyric acid; DPG, diphosphatidylglycerol; GL, unknown glycolipid; PG, phosphatidylglycerol; PL, unknown phospholipid.

\begin{tabular}{|ll|}
\hline Characteristic & \multicolumn{1}{c|}{ Strain $\mathbf{Z 3 3}^{\mathbf{T}}$} \\
\hline Whole-cell sugars & Rha, Glc, Gal, Man \\
Cell-wall amino acids & DAB, Glu, Gly, Ala \\
Major menaquinones & MK-12, MK-13 (58:35) \\
Polar lipids & DPG, PG, PL, 2GL \\
Acyl type & Acetyl \\
Fatty acid composition (\%) & \\
iso-C $\mathrm{C}_{15: 0}$ & $16 \cdot 3$ \\
anteiso-C $15: 0$ & $45 \cdot 6$ \\
iso- $\mathrm{C}_{16: 0}$ & $12 \cdot 4$ \\
$\mathrm{C}_{16: 0}$ & $1 \cdot 01$ \\
iso- $\mathrm{C}_{17: 0}$ & $3 \cdot 57$ \\
anteiso- $\mathrm{C}_{17: 0}$ & $20 \cdot 4$ \\
\end{tabular}

and by measuring the divergence between the thermal denaturation midpoint of homoduplex DNA and heteroduplex DNA $\left(\Delta T_{\mathrm{m}}\right)$ as described by Gonzalez \& Saiz-Jimenez (2005). These studies revealed significant differences between strain $\mathrm{Z33}^{\mathrm{T}}$ and its closest phylogenetic neighbours within the genus Agromyces. Hybridization experiments revealed DNA-DNA relatedness levels of $\leqslant 66 \%$ and a $\Delta T_{\mathrm{m}}$ of $\geqslant 5 \cdot 8{ }^{\circ} \mathrm{C}$ (equivalent to a

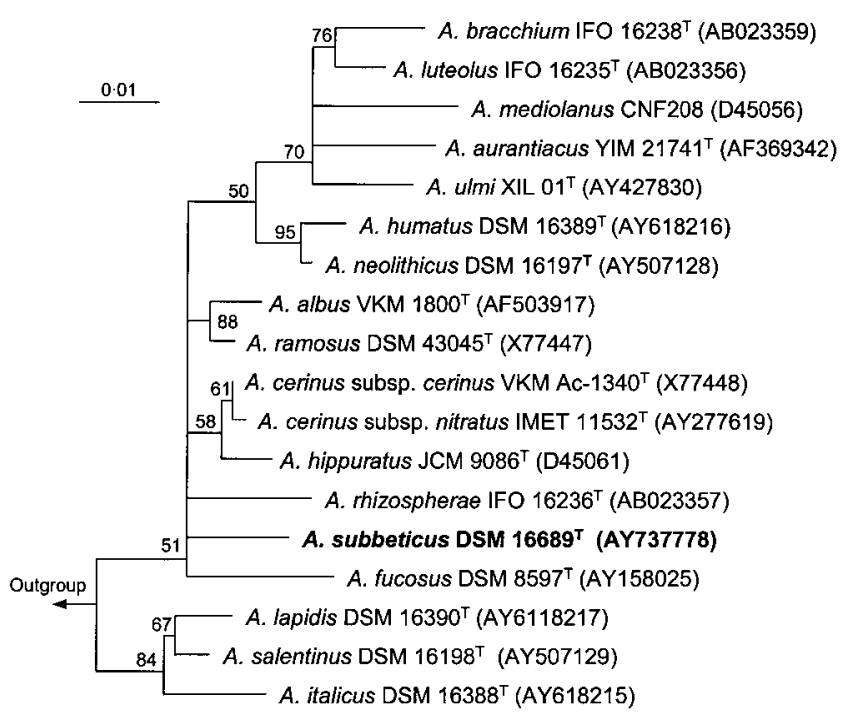

Fig. 1. Phylogenetic tree showing the proposed relationships between the type strains of Agromyces species and the studied strain $Z 33^{\top}$. Reliability values are given at branching points as percentages from 1000 trials. Corynebacterium sp. QSSC3-5 (GenBank accession number AF170740) was used as the outgroup (not shown). Strain names and accession numbers (in parentheses) for the species represented in the tree are shown. Bar, 0.01 nucleotide substitutions per site. 
DNA-DNA relatedness level of approximately $51 \%$, as proposed by Rosselló-Mora \& Amann, 2001). These values were below the $70 \%$ DNA-DNA relatedness and above the $5{ }^{\circ} \mathrm{C} \Delta T_{\mathrm{m}}$ recommended as cut-off points for the delineation of species (Wayne et al., 1987). These results indicate that strain $\mathrm{Z} 33^{\mathrm{T}}$ shows enough genomic coherence and low enough levels of DNA-DNA relatedness to its closest relatives to be considered as a novel species (Rosselló-Mora \& Amann, 2001; Stackebrandt et al., 2002).

The genotypic and phenotypic characteristics of strain $\mathrm{Z}_{3} 3^{\mathrm{T}}$ are consistent with its classification in the genus Agromyces (Gledhill \& Casida, 1969; Zgurskaya et al., 1992).

Strain $\mathrm{Z} 33^{\mathrm{T}}$ can be readily distinguished from representatives of recognized Agromyces species on the basis of a number of phenotypic properties (Table 1). DNA-DNA relatedness data support the differentiation between strain $\mathrm{Z}^{2} 3^{\mathrm{T}}$ and its closest relatives within the genus Agromyces. Based on the results of this polyphasic approach, we suggest the studied isolate represents a novel species of the genus Agromyces, for which the name Agromyces subbeticus sp. nov. is proposed.

\section{Description of Agromyces subbeticus sp. nov.}

Agromyces subbeticus (sub.be'ti.cus. N.L. masc. adj. subbeticus referring to the Subbetic Mountain Range, southern Spain, where the Cave of Bats is located).

Gram-positive, aerobic and microaerophilic actinomycete. Cells form branching hyphae $(0 \cdot 3-0 \cdot 5 \mu \mathrm{m}$ in width by $2 \cdot 5-4 \cdot 0 \mu \mathrm{m}$ in length) that break up into irregular rodshaped and diphtheroid fragments. Colonies are circular, convex, smooth and intense yellow. Colony diameter is about $1 \mathrm{~mm}$. Growth occurs between 6 and $37^{\circ} \mathrm{C}$ (optimally at $28^{\circ} \mathrm{C}$ ) and at $\mathrm{pH}$ values between 5 and $9 \cdot 5$. Growth occurs at up to $4 \% \mathrm{NaCl}$. It hydrolyses aesculin and starch, but not adenine or Tween 80 . Utilizes acetate, but not benzoate or DL-tartrate. Produces $\mathrm{H}_{2} \mathrm{~S}$. Indole, VogesProskauer and methyl red tests are negative. It produces acid from starch, arbutin, aesculin, D-fructose, glycogen and rhamnose, but not from DL-arabitol, dulcitol, 2ketogluconate, 5-ketogluconate, erythritol, $\beta$-gentiobiose, gluconate, inositol, D-lyxose, melezitose, sorbitol, L-sorbose, D-tagatose, D-turanose, L-xylose, methyl $\beta$-xyloside or xylitol. It produces alkaline phosphatase, esterase (C4), esterase lipase (C8), leucine arylamidase, valine arylamidase, cystine arylamidase, acid phosphatase, naphthol-ASBI-phosphohydrolase and $\beta$-glucosidase, but not lipase (C14), trypsin, $\alpha$-chymotrypsin, $\beta$-glucuronidase or $\alpha$ mannosidase. It is sensitive to chloramphenicol $(30 \mu \mathrm{g})$, imipenem $(10 \mu \mathrm{g})$, ofloxacin $(10 \mu \mathrm{g})$, oxytetracycline hydrochloride $(30 \mu \mathrm{g})$, rifampicin $(5 \mu \mathrm{g})$, streptomycin $(10 \mu \mathrm{g})$ and vancomycin hydrochloride $(30 \mu \mathrm{g})$, but not to lincomycin $(2 \mu \mathrm{g})$, methicillin $(5 \mu \mathrm{g})$, norfloxacin $(10 \mu \mathrm{g})$, nalidixic acid $(30 \mu \mathrm{g})$ or sulfonamide $(200 \mu \mathrm{g})$. Additional phenotypic characteristics are given in Table 1. Whole-cell sugars are rhamnose, glucose, galactose and mannose. Cell-wall amino acids are diaminobutyric acid, glutamic acid, glycine and alanine. Major menaquinones are MK-12 and MK-13. Polar lipids are diphosphatidylglycerol, an unknown phospholipid and two unknown glycolipids. Acyl type is acetyl. Major fatty acids are anteiso- $\mathrm{C}_{15: 0}$ $(45 \cdot 6 \%)$, anteiso- $\mathrm{C}_{17: 0}(20 \cdot 4 \%)$, iso- $\mathrm{C}_{15: 0}(16 \cdot 3 \%)$, iso$\mathrm{C}_{16: 0}(12 \cdot 4 \%)$, iso- $\mathrm{C}_{17: 0}(3 \cdot 57 \%)$ and $\mathrm{C}_{16: 0}(1 \cdot 01) . \mathrm{G}+\mathrm{C}$ content of the DNA is $71 \cdot 2 \mathrm{~mol} \%$.

The type strain, $233^{\mathrm{T}}\left(=\right.$ HKI $0340^{\mathrm{T}}=\mathrm{DSM} 16689^{\mathrm{T}}=$ NCIMB $14025^{\mathrm{T}}$ ), was isolated from a blue-grey cyanobacterial biofilm covering the walls of the Cave of Bats, Zuheros, Cordoba, southern Spain.

\section{Acknowledgements}

V. J. and L. L. are grateful to fellowships from the Council for Scientific Research (CSIC) through the European Social Funds, I3P programme and J.M.G. to a 'Ramón y Cajal' programme contract from the Ministry of Education and Science (MEC). This study was supported by project CATS (EVK4-CT2000-00028) and MEC project BTE200204492-C02-01. We thank Christiane Weigel, Carmen Schult and Renate Schön for their technical assistance.

\section{References}

Dorofeeva, L. V., Krausova, V. I., Evtushenko, L. I. \& Tiedje, J. M. (2003). Agromyces albus sp. nov., isolated from a plant (Androsace sp.). Int J Syst Evol Microbiol 53, 1435-1438.

Gledhill, W. E. \& Casida, L. E. (1969). Predominant catalase-negative soil bacteria. III. Agromyces, gen. nov., microorganisms intermediary to Actinomyces and Nocardia. Appl Microbiol 18, 340-349.

Gonzalez, J. M. \& Saiz-Jimenez, C. (2005). A simple fluorimetric method for the estimation of DNA-DNA relatedness between closely related microorganisms by thermal denaturation temperature. Extremophiles 9, 75-79.

Groth, I., Schumann, P., Weiss, N., Martin, K. \& Rainey, F. A. (1996). Agrococcus jenensis gen. nov., sp. nov., a new genus of actinomycetes with diaminobutyric acid in the cell wall. Int J Syst Bacteriol 46, 234-239.

Jurado, V., Groth, I., Gonzalez, J. M., Laiz, L. \& Saiz-Jimenez, C. (2005a). Agromyces salentinus sp. nov. and Agromyces neolithicus sp. nov., two novel species of the genus Agromyces. Int J Syst Evol Microbiol 55, 153-157.

Jurado, V., Groth, I., Gonzalez, J. M., Laiz, L., Schuetze, B. \& SaizJimenez, C. (2005b). Agromyces italicus sp. nov., Agromyces humatus sp. nov. and Agromyces lapidis sp. nov., isolated from Roman catacombs. Int J Syst Evol Microbiol 55, 871-875.

Li, W.-J., Zhang, L.-P., Xu, P., Cui, X.-L., Xu, L.-H., Zhang, Z., Schumann, P., Stackebrandt, E. \& Jiang, C.-L. (2003). Agromyces aurantiacus sp. nov., isolated from a Chinese primeval forest. Int J Syst Evol Microbiol 53, 303-307.

Ludwig, W., Strunk, O., Westram, R. \& 29 other authors (2004). ARB: a software environment for sequence data. Nucleic Acids Res 32, 1363-1371.

Ortiz-Martinez, A., Gonzalez, J. M., Evtushenko, L. I., Jurado, V., Laiz, L., Groth, I. \& Saiz-Jimenez, C. (2004). Reclassification of Agromyces fucosus subsp. hippuratus as Agromyces hippuratus sp. nov., comb. nov. and emended description of Agromyces fucosus. Int J Syst Evol Microbiol 54, 1553-1556. 
Prauser, H. \& Falta, R. (1968). Phagensensibilität, ZellwandZusammensetzung und Taxonomie von Actinomyceten. $Z$ Allg Mikrobiol 8, 39-46 (in German).

Rivas, R., Trujillo, M. E., Mateos, P. F., Martínez-Molina, E. \& Velázquez, E. (2004). Agromyces ulmi sp. nov., xylanolytic bacteria from Ulmus nigra in Spain. Int J Syst Evol Microbiol 54, 1987-1990.

Rosselló-Mora, R. \& Amann, R. (2001). The species concept for prokaryotes. FEMS Microbiol Rev 25, 39-67.

Stackebrandt, E., Frederiksen, W., Garrity, G. M. \& 10 other authors (2002). Report of the ad hoc committee for the reevaluation of the species definition in bacteriology. Int J Syst Evol Microbiol 52, 1043-1047.

Strimmer, K. \& von Haeseler, A. (1996). Quartet puzzling: a quartet maximum-likelihood method for reconstructing tree topologies. $\mathrm{Mol}$ Biol Evol 13, 964-969.

Suzuki, K., Sasaki, J., Uramoto, M., Nakase, T. \& Komagata, K. (1996). Agromyces mediolanus sp. nov., nom. rev., comb. nov., a species for "Corynebacterium mediolanum" Mamoli 1939 and for some aniline-assimilating bacteria which contain 2,4diaminobutyric acid in the cell wall peptidoglycan. Int $J$ Syst Bacteriol 46, 88-93.
Takeuchi, M. \& Hatano, K. (2001). Agromyces luteolus sp. nov., Agromyces rhizospherae sp. nov. and Agromyces bracchium sp. nov., from the mangrove rhizosphere. Int J Syst Evol Microbiol 51, 1529-1537.

Wayne, L. G., Brenner, D. J., Colwell, R. R. \& 9 other authors (1987). Report of the ad hoc committee on reconciliation of approaches to bacterial systematics. Int J Syst Bacteriol 37, 463-464.

Yokota, A., Takeuchi, M., Sakane, T. \& Weiss, N. (1993). Proposal of six new species of the genus Aureobacterium and transfer of Flavobacterium esteraromaticum Omelianski to the genus Aureobacterium as Aureobacterium esteraromaticum comb. nov. Int J Syst Bacteriol 43, 555-564.

Zgurskaya, H. I., Evtushenko, L. I., Akimov, V. N., Voyevoda, H. V., Dobrovolskaya, T. G., Lysak, L. V. \& Kalakoutskii, L. V. (1992). Emended description of the genus Agromyces and description of Agromyces cerinus subsp. cerinus sp. nov., subsp. nov., Agromyces cerinus subsp. nitratus sp. nov., subsp. nov., Agromyces fucosus subsp. fucosus sp. nov., subsp. nov., and Agromyces fucosus subsp. hippuratus sp. nov., subsp. nov. Int J Syst Bacteriol 42, 635-641.

Ziemke, F., Höfle, M. G., Lalucat, J. \& Rosselló-Mora, R. (1998). Reclassification of Shewanella putrefaciens Owen's genomic group II as Shewanella baltica sp. nov. Int J Syst Bacteriol 48, 179-186. 